\title{
SLC16A3 Gene
}

National Cancer Institute

\section{Source}

National Cancer Institute. SLC16A3 Gene. NCI Thesaurus. Code C124124.

This gene is involved in transmembrane transport of monocarboxylates. 